\title{
The prevalence of environmentral colonization of Legionella in hospital water systems in Taiwan - a 20 hospital surveillance
}

\author{
YE Lin ${ }^{1 *}, Y J \operatorname{Lin}^{1}$, HY Shih ${ }^{1}$, YS Chen ${ }^{2}$ \\ From International Conference on Prevention \& Infection Control (ICPIC 2011) \\ Geneva, Switzerland. 29 June - 2 July 2011
}

\section{Introduction / objectives}

Legionnaires' disease is a major cause of hospital and community acquired pneumonia. Hospital-acquired Legionnaires' disease is directly linked to the presence of Legionella in hospital drinking water. The objective is to systematically investigate the presence of Legionella and its colonization rate in hospital water systems in Taiwan.

\section{Methods}

Twenty hospitals (Hospitals A to T) throughout Taiwan (8 in northern, 2 in central, 7 in southern, 2 in eastern Taiwan, and one in rural island) were cultured for Legionella. We followed the standardized protocol to perform environmental cultures using (1) water samples; (2) BCYE and DGVP culture media; (3) latex agglutination test (LAX) and direct fluorescent antibody (DFA) technique for L. pneumophila speciation and serotyping. We also perform speciation for $L$. micdadei since it is implicated in transplant patients.

\section{Results}

Among 706 water samples collected during 2009 2011 period, 21\% (149/706) were positive for Legionella. 65\% $(13 / 20)$ of hospital water systems are positive for Legionella; 2 have $>30 \%$ site positive, 7 are between $10 \%$ $30 \%$ site positive, and 4 are $<10 \%$ site positive. L. pneumophila serogroups $1,3,5,6,7$, were isolated from $62 \%$ (8/13), 31\% (4/13), 8\% (1/13), 38\% (5/13), and 8\% (1/13) of the hospitals, respectively. Five hospitals yielded L. species, but none of them were $L$. micdadei.

\section{Conclusion}

This study allow health official and healthcare professionals for the development of water safety plan to better protect patients and residents of Taiwan in an attempt to prevent Legionnaires' diseases.

\section{Disclosure of interest}

None declared.

\section{Author details}

${ }^{1}$ National Kaohsiung Normal University, Kaohsiung, Taiwan, China.

${ }^{2}$ Kaohsiung Veterans General Hospital, Kaohsiung, Taiwan, China.

Published: 29 June 2011

doi:10.1186/1753-6561-5-S6-P240

Cite this article as: Lin et al:: The prevalence of environmentral

colonization of Legionella in hospital water systems in Taiwan - a 20

hospital surveillance. BMC Proceedings 2011 5(Suppl 6):P240.
Submit your next manuscript to BioMed Central and take full advantage of:

- Convenient online submission

- Thorough peer review

- No space constraints or color figure charges

- Immediate publication on acceptance

- Inclusion in PubMed, CAS, Scopus and Google Scholar

- Research which is freely available for redistribution

\section{() Biomed Central}

